\title{
A Lacanian Reading of the Two Novels The Scarlet Letter And Private Memoirs And Confessions of A Justified Sinner
}

\author{
Marjan Yazdanpanahi \\ $\mathrm{PhD}$ in English Literature (Romanticism) - Lancaster University \\ Bailrigg, Lancaster UK, LA1 4YW \\ marjazdanmy@yahoo.com
}

\begin{abstract}
This paper discusses two novels The Private Memoirs and Confessions of a Justified Sinner and The Scarlet Letter written by James Hogg and Nathaniel Hawthorn from the perspective of Jacques Lacan theories: the mirror stage, the-name-of-the-father and desire. The mirror stage refers to historical value and an essential libidinal relationship with the body-image. The-name-of-thefather is defined as the prohibitive role of the father as the one who lays down the incest taboo in the Oedipus complex. Meanwhile, desire is neither the appetite for satisfaction, nor the demand for love, but the difference that results from the subtraction of the first from the second.
\end{abstract}

Keywords: Lacanian Reading, The Mirror Stage, The-Name-Of-The-Father And Desire

\begin{abstract}
Abstrak
Dalam jurnal ini akan dibahas dua novel yang berjudul The Private Memoirs and Confessions of a Justified Sinner dan The Scarlett Letter yang merupakan karya dari James Hogg dan Nathaniel Hawthorn dengan menggunakan perspektif Jacques Lacan dalam teori-teorinya yang berkenaan dengan tahap cermin panggung, nama-sang-ayah, dan hasrat. Cermin panggung merujuk kepada nilai historis dan hubungan libidinal utama dengan kesan utama. Nama-sang-ayah didefinisikan sebagai peran penghalang dari seorang ayah sebagai seseorang yang melakukan perbuatan tabu berupa perzinahan sebagai penderita Oedipus complex (penyuka orang yang lebih tua). Sementara itu, hasrat yang dimaksud disini bukanlah berupa nafsu untuk kepuasan ataupun keinginan untuk bercinta, namun tak lain berupa selisih hasil pengurangan nilai yang pertama dari yang kedua.
\end{abstract}

Kata Kunci: Membaca Ala Lacania, Cermin Panggung, Nama-Sang-Ayah, Dan Hasrat 


\section{Introduction}

Psychoanalytic studies of literature have become of the growing interest in literary studies. Jacques Lacan is one of the most important figures in this area. His theories have influenced psychoanalysis, literary theory and philosophy.

It is the purpose of this paper to see how we can have a Lacanian reading of the two novels The Private Memoirs and Confessions of a Justified Sinner by James Hogg and The Scarlet Letter by Nathaniel Hawthorn. The interesting thing about this is that these two novels were written and

published nearly one century before Lacan's ideas were introduced to the world. In fact, he was not born until fifty years after the publication of these two novels. However, if we look at his theories, we will see that they are true about the characters and what happens to them in these two novels.

This paper deals with three of his most important theories including the mirror stage, the-name-of-the-father and desire. At first, we will see how and in which part of these two novels the mirror stage takes place. We will then see how the-name-of-the-father comes into the scene. This paves the way to find some traces of desire in thee two novels.

\section{Discussion}

If we look at The Private Memoirs and Confessions of a Justified Sinner, we will see that when Robert Wringhim meets the Devil for the first time, he finds the Devil's face and features completely the same as his own face:

What was my astonishment, on perceiving that he was the same being as myself! The clothes were the same to the smallest item. The form was the same; the apparent age; the colour of the hair; the eyes; and as far as recollection could serve me from viewing my own features in a glass, the features too were the very same. 
(Hogg, 1981:116-117)

Robert stresses the fact that when he looks at the Devil, it seems as if he has looked himself in a piece of glass. The reason is that the Devil seems so similar to him in features. Therefore, looking at the Devil is just the same as looking in a mirror or a piece of glass. What's more, at first, he tries to avoid him but he can't and that's what happens in the mirror stage, a theory by Lacan. The mirror stage is a stage at the life of a six-month-old child. The Child looks at the image of himself in the mirror. This is the first time he sees himself as a unified whole. Before that, he was conscious of himself as just a fragmented body. However, when he sees himself in the mirror, he sees that the head is connected to the body and so are the hands and the legs. However, there is a threat in this. According to Dylan Evans, 'the synthesis of this image produces a sense of contrast with the uncoordination of the body which is experienced as a fragmented body; this contrast is felt by the infant as a rivalry with its own image, because the wholeness of the image threatens the subject with fragmentation, and the mirror stage thereby gives rise to an aggressive tension between the subject and the image' (Evans, 1996:115). This is what Jacques Lacan says about the mirroe stage:

[The mirror stage is] a phenomenon to which I assign a twofold value. In the first place, it has historical value as it marks a decisive turningpoint in the mental development of the child. In the second place, it typifies an essential libidinal relationship with the body-image.

(Lacan, 1951b:14 in Evans, 1996:115)

These two aspects of the mirror stage including its historical value and the relationship of the child to its image will be discussed here in relation to these two novels. We will first see how the characters in the novels feel about their images and then we will see how they change after they see their own images. 
In the mirror stage, when an infant sees his own image in the mirror, he feels that he is threatened by that unified image which he can see there. The child has to solve this problem. Therefore, as Evans writes, 'in order to resolve this aggressive tension, the subject identifies with the image' (Evans, 1996:115). This is what happens to Robert in The Confessions of a Justified Sinner. At first, there is a distancing force between Robert and the Devil. However, he is soon attracted to him and in fact identifies with him because he starts to obey him for the rest of his life. This is how Robert describes his feelings about his first meeting with the Devil (Gil-Martin):

I tried to shun him being bent on my own contemplations; but he cast himself in my way, so that I could not well avoid him; and more than that, I felt a sort of invisible power that drew me towards him, something like a force of enchantment which I could not resist.

(Confessions of a Justified Sinner, p. 116)

Therefore, Robert is attracted to the Devil who is like his own image. Robert's character is fragmented like that of a child and that's why he identifies with the Devil when he sees him. He has some religious conflicts before he meets the Devil which shows us that his character is fragmented. He commits some sins and he knows it's wrong to do so. However, when he compares them to some other big sins which he does not commit he thinks that he might be forgiven:

That I was a great, a transcendent sinner, I confess. But still I had hopes of Forgiveness, because I never sinned from principle, but accident; and then I always tried to repent of these by the slump for individually it was impossible; and though not always successful in my endeavours, I could not help that.

(Ibid, p. 116)

This suggests that Robert is not really sure about himself. He knows that he is a big sinner and he is not sure whether or not he is forgiven. Just before he meets Gil-Martin, he is welcomed by his father 'into the 
community of the just upon earth' (Confessions of a Justified Sinner, p. 115). His mother also welcomes him into 'the society of the just made perfect' (ibid, p.115). Such phrases as 'the just' and 'the just made perfect' turn out to be ironical because later in the novel we see that Robert commits sins and also crimes. The word perfect which is used ironically here can show the fragmented and imperfect character of Robert which seeks to become a unified whole and perfect by befriending Gil-Martin. Gil-Martin for Robert is just like the image of a child which according to Sean Homer 'provides $\mathrm{him} / \mathrm{her}$ with a sense of unification and wholeness. Therefore, the character of Gil-Martin is a perfect one and therefore superior to his own which is not perfect. That's why when the Devil tries to convince him that he is one of 'the elect', he is surprised that he is given such a high status by such a superior character:

I confess that I was greatly flattered by these compliments paid to my abilities by a youth of such superior qualifications.

(Ibid, p. 125)

If we look at the exact definition of the mirror stage in $A n$ Introductory Dictionary of Lacanian Psychology, we will see that it is described as 'the formation of the ego via the process of identification; the ego is the result of identifying with one's own specular image' (Evans, 1996: 115). That's what has happened to Robert. He forms his ego for his whole life after he identifies with the Devil. The Devil is his specular image which in Lacan's theory is the image of one in the mirror as one looks at himself in the mirror. He changes himself according to what Gil-Martin says. Therefore, he tries to identify with him.

According to Dylan Evans, in Lacan's theory, 'the little other is the other who is not really other, but a reflection and projection of the ego' (ibid. p.133). Therefore, Gil-Martin can be considered as the projection of Robert's 
ego and consequently, his other. This other is not different from the subject. It is somehow the same. It is the image of the subject with which the subject (Robert) becomes one. If we look at what Lacan says about this other, we find out about the similarity of the subject to his own image (other). Lacan talks about the 'phenomena of transitivism in which one finds the infant taking as equivalent his own action and that of the other' (Miller, 1988: 169).

We can see the word 'transivitism' here. Therefore, there is a change for the infant when he looks in the mirror. We can see the moment of change for Robert too. The Devil starts to exercise his influence on Robert from this point in the novel. He acts according to the Devil's will till the end of his life. In fact, he obeys the Devil in every respect. In other words, he becomes one with the Devil and that's what Lacan thinks to happen in what he calls the imaginary order. The imaginary order is one of the three orders in Lacan's theory which include symbolic, imaginary and the real order. According to Dylan Evans, 'the basis of the imaginary order continues to be the formation of the ego in the mirror stage' (Evans, 1996: 82). Therefore, we can see that this mirror stage is related to the imaginary order. As Evans writes, 'the principal illusions of the imaginary are those of wholeness, synthesis, autonomy, duality and, above all similarity'.(ibid, p.82). Robert is united with the Devil for the rest of his life. That's what happens to him after he identifies with the Devil as his own image. We can easily see these ideas of wholeness, synthesis and similarity here which were 'the principal illusions of the imaginary'. Robert and the Devil make a whole for the rest of the story. Wherever one is, the other one can be found too. This is more obvious when Robert says: 'I rejoiced in him, was proud of him, and soon could not live without him' (Confessions of a Justified Sinner: 127). Elsewhere, he calls him something like his shadow: 'he was constant to me as my shadow' (ibid, p. 132). That is how they make one whole. By becoming one with the 
Devil Robert tries to gain autonomy too. The Devil convinces him that he is one of 'the elect'. He tells him that he has been chosen to undertake a great mission:

You are dedicated to the great work of the Lord; for which reasons I have resolved to attach myself as closely to you as possible, and to render you all the service of which my poor abilities are capable.

(ibid, p. 125)

That's when he sees himself separate and different from others. That's how he tries to gain autonomy. In fact, he thinks he has the power to do whatever is good (in his opinion) on earth. This is how it seems that Robert has gone through the mirror stage.

The mirror stage happens in The Scarlet Letter too. When Hester and Pearl go to the forest and they meet Dimmesdale there, Pearl seems to go through the mirror stage while her mother is talking to Dimmesdale. This happens when the child near the water. Pearl looks herself in the water and the water Pearl looks herself in acts as a mirror. She can see herself in it and then she goes through this mirror stage:

Just where she had paused the brook chanced to form a pool, so smooth and quiet that it reflected a perfect image of her little figure, with all the brilliant picturesqueness of her beauty, in its adornment of flowers and wreathed foliage, but more refined and spiritualized than reality.

(Confessions of a Justified Sinner: 141)

This is the moment of change for Pearl. This is the moment when she enters the imaginary order. She sees her image in the water. The image is hers, but as we can see in this quotation, it is more 'refined'. Therefore, we can see that this image is superior to her.

This image changes her. This is the moment when she disobeys her mother. The reason is that she has gained autonomy which Lacan talks about 
in his theory of the imaginary order. In fact, she becomes independent. That's the moment when Hester feels some change in Pearl's relationship to her:

Hester felt herself, in some indistinct and tantalizing manner, estranged from Pearl; as if the child, in her lonely ramble through the forest, had strayed out of the sphere in which she and her mother dwelt together, and was now vainly seeking to return to it.

(The Scarlet Letter: 141)

That autonomy of the child becomes more obvious when Hester calls her but she doesn't take notice. She stays there looking at Hester and Dimmesdale. Now she has the power to oppose her mother. For example, we see that 'Pearl, without responding in any manner to these honey-sweet expressions, remained on the other side of the brook'(ibid,P. 141). Later on we see an authoritative reaction by her: 'Assuming a singular air of authority, Pearl stretched out her hand, with the small forefinger extended, and pointing evidently towards her mother's breast' (The Scarlet Letter: 142). The word authority is explicitly stated here. This shows that she has gained autonomy. That's how it seems that Pearl experiences some kind of mirror stage.

There is a contrast between these two novels regarding the mirror stage through which these two characters go. In The Private Memoirs and Confessions of a Justified Sinner, Robert's meeting with the Devil makes him go through such a process as the mirror stage and become one with somebody else who is a projection of himself. However, in The Scarlet Letter, Pearl goes through this stage and becomes one with her own image. In fact, she achieves wholeness by trying to be unified with her own image. She succeeds in becoming autonomous because she has the power to oppose her mother when she calls her to her side. Robert, on the other hand, tries to become one with the Devil but doing so makes him fragmented at the end. He does not get the result he was seeking. He loses control over his body and actions instead of gaining control over them. This was not what he was looking for. 
He liked to have the power to wipe out evil on earth but the process turns out to be a different one. Therefore, he does not really gain that autonomy for which he makes himself unified with the Devil. This is so horrible that Robert thinks Gil-Martin is actually his second self because he is not conscious of many crimes he is accused of near the end of his memoirs:

I was a being incomprehensible to myself. Either I had a second self, who transacted business in my likeness, or else my body was at times possessed by a body over which it had no control, and of whose actions my own soul was wholly unconscious.

(Confessions of a Justified Sinner: 182)

Therefore, we can see that he is not sure whether it is him committing these crimes or an external being. There has always been much debate about whether this Gil-Martin really exists or not. According to Douglas Gifford, 'the Devil and the other supernatural apparitions may not exist at all, and may merely be a link with creatures of a diseased mind' (Gilford, 1976: 144). Therefore, the Devil might not have had an external existence. All of these incidents can be a product of Robert's mind. This is explicitly stated at the end of the novel when we are told that he may have been 'a religious maniac, who wrote and wrote about a deluded creature, till he arrived at that height of madness, that he believed himself the very object whom he had been all along describing' (Confessions of a Justified Sinner: 254).

Therefore, we see that there is a possibility that Gil-Martin does not have an external existence. There can be a Lacanian reading of this. If we consider Gil-Martin's existence as a hallucination of Robert's mind, the reason for this can be found by looking at Lacan's definition of the word 'hallucination'. According to Lacan, 'psychotic hallucinations are a consequence of the operation of foreclosure. Foreclosure refers to the absence of the name-of-the-father' (Evans, 1996: 77). 
There is a need to define Lacan's theory of the name-of-the-father here. In An Introductory Dictionary of Lacanian Psychoanalysis, this expression is defined as 'the prohibitive role of the father as the one who lays down the incest taboo in the Oedipus complex' (ibid, p. 119). In Oedipus complex, the child has some hostile feelings toward his parent. The term was coined by Sigmund Freud. He thought that only boys are jealous of their father. However, Lacan thought that this is possible for both girls and boys. He believed that girls also become jealous of their father when his presence separates the child from the mother. This prohibitive role of the father is called the-name-of-the-father. His presence imposes some 'laws' upon the child because the child cannot be with his mother as much as he likes. The child finds out that his mother needs his father and likes to be with him.

This is what seems to be lacking in The Private Memoirs and Confessions of a Justified Sinner. The father figure is really absent in this novel. We have the Laird of Dalcastle to whom her mother had married but supposedly he is not his real father because he denies that Robert is his son:

I was the second son of this unhappy marriage, and, long ere before I was born, my father according to the flesh disclaimed all relation or connection with me, and all interest in me, save what the law compelled him to take, which was togrant me a scanty maintenance.

(Confession of a Justified Sinner: 98)

He calls Wringhim his father. Throughout the novel it is suggested that Wringhim is his real father. Robert himself puts the word 'father' in italics when he writes, "No," said my pastor, and father, (as I shall henceforth dominate him,)' (ibid, p. 99). We never see him feeling jealous towards a father. According to Lacan, this absence of the father figure can lead to hallucination.

However, in The Scarlet Letter we have the opposite case. When Pearl and Hester are in the forest and Hester meets Dimmesdale she talks and 
walks with him. It seems that Pearl has a special feeling about the relationship between Dimmesdale and her mother:

Now she fixed her bright, wild eyes on her mother, now on the minister, now included them both in the same glance; as if to detect and explain to herself the relation which they bore to one another.

(The Scarlet Letter: 142)

She does not seem to like it at all. This is directly expressed in the novel when we are told that 'whether influenced by the jealousy that seems instinctive with every petted child towards a dangerous rival, or from whatever caprice of her freakish nature, Pearl would show no favor to the clergyman' (ibid, p. 144). This shows us exactly the Oedipus complex in the child and consequently her experiencing the-name-of-the-father. Now that she sees Dimmesdale with her mother, she considers him as a 'rival'. He has been talking to her mother while she was away. Before this meeting with Dimmesdale, Hester is with her daughter all the time. Pearl has never separated from her mother but now the minister's presence has made her separate from her mother. That's why when the minister leaves, she is happy and feels that she can be with her mother again. She considers her mother her own just after the minister leaves:

...so that these two fated ones, with Earth's heaviest burden on them, might there sit down together, and find a single hour's rest and solace. And was Pearl, too, lightly dancing from the margin of the brook,-now that the intrusive third person was gone, and taking her old place by her mother's side.

(The scarlet Letter: 145)

Therefore, we can see that she feels the minister has taken her place. He is called 'the intrusive third person'. That's exactly what the Oedipus complex is about. The father figure here is considered as a third party who prohibits the child's relationship with her mother. Here, Pearl has such an experience. In Lacan's theory, this can happen to girls too and we see that it 
happens to Pearl. Theses feelings are because the minister is her real father. Although she is not conscious of the fact yet, she can feel the threat of his presence. That's why she feels somehow jealous of him.

All these happen because Hester is really in love with Dimmesdale. They have been lovers since seven years before. We know that the subtitle of The Scarlet Letter is 'A Romance'. This proves that The Scarlet Letter is in fact a love story. From the beginning, there are some references to the love that is hidden in the story and is going to be revealed later. According to Ernest Sandeen, 'what is brought out most forcefully by her statuesque yet elegant figure, her abundance of dark, glossy hair, her regular features and rich complexion, her "marked brow and deep black eyes," is an impression of great erotic power' (Sandeen: 352). This is when Hester comes out of the prison door at the beginning of the story. According to Mark Van Doren also, 'She is said to cast a spell over those who behold her' (Doren, 1949: 151). He goes on to say that "she is a passionate woman whom Hawthorn does not need to call passionate, for he has the evidence' (Doren: 151). One of the evidences he thinks is 'her continuing love, so unconfessed that we can only assume it to be there'(ibid, 151).

The descriptions given by Hawthorn about Hester help us develop a positive attitude towards Hester from the beginning although everybody else in that small town criticize her for what she had done. She is so much in love that she doesn't feel any remorse for her illegal relationship with Dimmesdale. Even when she appears out of the prison door, the description we get of her is of a determined woman:

Until, on the threshold of the prison door, she repelled him, by an action marked with natural dignity and force of character, and stepped into the open air, as if by her own free-will.

(The Scarlet Letter: 39) 
Here, we can see that she is not ashamed of what she has done. It seems as if she has come in front of people 'by her own free-will'. This is because she is in love and she doesn't think what she has done has been wrong. According to Ernest Sandeen also, 'Hester Prynn can never bring herself to regard her relations with Arthur Dimmesdale as "sinful"' (Sandeen: 352). The reason is that even seven years later, again we see her in the forest with Dimmesdale trying to convince him to go away with her. She cannot forget Dimmesdale. We can easily see Hester's passionate reaction in the forest. When Hester reveals that Chillingworth is her husband, Dimmesdale is so offended that he thinks he cannot forgive her: 'Woman, woman, thou art accountable for this! I cannot forgive thee' (The Scarlet Letter: 132).

But this is the worst that can happen to Hester. She cannot tolerate this. We see that 'all the world had frowned on her,-for seven long years had it frowned upon this lonely woman,- and still she bore it all, nor ever once turned away her firm, sad eyes. Heaven, likewise, had frowned upon her, and she had not died. But the frown of this pale, weak, sinful, and sorrow-stricken man was what Hester could not bear and live' (ibid, p. 132-133). It is here we can see the extent of love Hester feels for Dimmesdale. In fact, she desires him.

Desire is a word for which Lacan has a theory. It is important to him that the word 'desire' not be confused with the words 'need' and 'demand'. For Lacan need is 'a purely biological instinct, an appetite which emerges according to the requirements of the organism and which abates completely (even if only temporarily)' (Evans, 1996: 37). Therefore, when a baby is hungry and cries, the hunger he feels is a need. However, he should articulate his need to make his mother notice him. According to Evans, in Lacan's theory, 'need must be articulated in demand' (ibid). Therefore, the vocal expression of the need is called demand. In this example, after the mother 
feeds the baby, her presence 'soon aquires an importance in itself, an importance that goes beyond the satisfaction of need, since this presence symbolizes the Other's (the mother's) love. Hence, demand soon takes on a double function, serving both as an articulation of need and as a demand for love' (ibid). However, when the subject (baby) asks for more love from the mother, he sees that the mother cannot provide him with 'that unconditional love which the subject craves'(ibid). And according to Evans, the result is that 'the other aspect of demand, the craving for love, remains unsatisfied, and this leftover is desire' (ibid). After all these explanations, the definition Lacan has given us is that 'desire is neither the appetite for satisfaction, nor the demand for love, but the difference that results from the subtraction of the first from the second'(Evans, 1996: 37). Therefore, we can see that one's demand for love should remain unfulfilled for 'desire' to form.

If we consider Hester's case, we will see that her marriage is unsuccessful. When she is speaking to Chillingworth, she says: 'thou knowest that I was frank with thee. I felt no love, nor feigned any' (The Scarlet Letter: 53). Therefore, we see that she felt no love for her husband. That's why that aspect of her demand, the one for 'unconditional love' has remained unanswered. Therefore, she desires love. That's what she has found in Dimmesdale. She doesn't love her husband. We are told in the novel that Chillingworth is an old man. He is often referred to as 'old Chillingworth' The contrast between Chillingworth and Hester is felt more when we read those descriptions of Hester's beauty. The description we read at the beginning when she comes out of the prison door is one example. Even after seven years, when she removes the scarlet letter from her breast and takes off her cap from her hair, 'down it fell upon her shoulders, dark and rich, with at once a shadow and a light in its abundance, and imparting the charm of softness to her features' (The Scarlet Letter: 138). 
The whole novel suggests that she does not love her husband. It seems that her marriage has been unsuccessful. Even Chillingworth confesses to this. He also thinks that her marriage to her has been wrong. He says it somewhere at the beginning of the novel when he meets Hester in prison:

"I,-a man of thought,-the bookworm of great libraries,-a man already in decay, having given my best years to feed the hungry dream of knowledge, what had I to do with youth and beauty like thine own!

(Ibid, p. 53)

According to Darrel Abel also, Chillingworth 'married her before she was mature enough to know the needs of her nature' (Abel, 1961: 302). That's why she feels no love for Chillingworth and this leads to her desire for Dimmesdale. He also desires her. He acts as his lover all throughout the novel. He is a religious figure but he loves Hester so much that he transgresses the rules of his religion and still feels no remorse. This is what he tells Hester: 'Of penance I have had enough! Of penitence there has been none' (The Scarlet Letter: 130). This shows that he has had no repentance. Therefore, he does not really regret what he has done. According to Ernest Sandeen, 'the obvious explanation would seem to be that in some unacknowledged depth of his psyche he is still in love and can no more regret his passion than Hester can regret hers' (Sandeen: 354). Therefore, we see that he is still thinking of Hester and loves her. That's why when Hester asks him to flee with her, he agrees and all the love which he felt for Hester returns:

"Do I feel joy again?" cried he, wondering at himself. "Methought the germ of it was dead in me! Oh Hester, thou art my better angel! I seem to have flung myself- sick, sin-stained, and sorrow-blackeneddown upon these forest leaves, and to have risen up all made anew, and with new powers to glorify Him that hath been merciful. This is already a better life! Why did we not find it sooner?"

(The Scarlet Letter: 137) 
Dimmesdale and Hester desire each other but they can't be with each other. That's why we can use the word 'desire' because desire in never fulfilled. Lacan talks about 'the unconditional love' in his theory. The other party is not capable of fulfilling the subject with that kind of love. That's what happens to Hester. She demands love from her husband. However, he can't give her this kind of love because she doesn't love him. She tries to find it in Dimmesdale but again her desire can't be fulfilled. The reason is that Dimmesdale is a clergyman who has already transgressed the borderlines with having this illegal relationship with Hester, a married woman. He confesses at the end of the novel and they never join each other. Therefore, the desire is still unanswered and that's a part of the definition of this word.

In The Private Memoirs and Confessions of a Justified Sinner also, we can feel this desire in Robert's mother. From the beginning of the story we can see that the marriage is an unhappy one. Lady Dalcastle seems so devoted to religion that she cannot forget her prayers even on the night of her marriage: 'Sure, Mr. Colwan, you won't go to bed to-night, at such an important period of your life, without first saying prayers for yourself and me' (Confessions of a Justified Sinner: 4).

However, the husband is the exact opposite. He is not devoted to religion at all. We are told that 'the laird was what his country neighbours called "a droll, careless chap," with the very limited proportion of the fear of God in his heart, and very nearly as little of the fear of man' (Confessions of a Justified Sinner: 2). That's why when Lady Dalcastle asks him to say prayers at the night of their marriage, he answers: 'Prayers, Mistress! Lord help your crazed head, is this a night for prayers?' (ibid, p. 4). This discordance becomes more obvious the day after they get married. When the laird searches for his wife and finds her the next day, Lady Dalcastle says: 'Sir, I will let you know, that I detest your principles and your person alike' 
(ibid, p. 8). Louis Simpson also calls the wife 'a Presbyterian bigot' (Simpson and Hogg, 1962: 74). The word bigot suggests the extent to which she is strict about religion.

Therefore, we can easily feel how different this husband and wife are. That's why Lady Dalcastle feels no love for her husband. Her husband is not religious at all and that's what is lacking in him. However, she can see this divinity in Mr. Wringhim. He is religious enough for her. Even at the night of their marriage the only person whose company she enjoys is the minister:

The only enjoyment in which she appeared to partake, was in now and then stealing a word of sweet conversation with her favorite pastor about divine things.

(Confessions of a Justified Sinner: 3)

That's why she is always with him and he acts as her counselor. Robert is also brought up under his care: 'Robert was brought up with Mr. Wringhim, the laird paying a certain allowance for him yearly' (ibid, p. 18).

Therefore, her desire for love is also unanswered and that's why she is always with Wringhim. He suits her better because he is religious. That's how she tries to satisfy herself. In short, she desires Wringhim. This is how desire, one of the theories of Lacan is true about this novel too.

\section{Conclusion}

In conclusion, we can see how it is possible to have a Lacanian reading of the two novels The Private Memoirs and Cofessions of a Justified Sinner and The Scarlet Letter although the writers did not have such a thing in mind when they wrote these novels. However, psychoanalysis is concerned with human nature. Therefore, it should be true about all men throughout the history of mankind no matter when and where they lived. 
We could see how Robert and Pearl go through the mirror stage. The theory of the-name-of-the-father was then brought in and was related to the mirror stage. This was where there was a contrast between these two novels. We could also see how it was possible that Robert had had hallucination in the novel. At the end, desire in Hester and Lady Dalcastle was dealt with and the fact that their marriages were unsuccessful. And that's how Lacan has got a theory for all of these.

\section{References}

Abel, Darrel. 'Hawthorn's Hester' in Gross, Seymore, Bradley, Sculley, Beatty, Richmond Croom, Long, E. Hudson (eds). 1961. The Scarlet Letter. $3^{\text {rd }}$ edition. New York and London: W.W. Norton \& Company. pp. 300-308

Doren, Mark Van. 1949. Nathaniel Hawthorne. The United States of America: William Sloan Associates, Inc.

Evans, Dylan. 1996. An Introductory Dictionary of Lacanian Psychoanalysis. London: Brunner-Routledge.

Gilford, Douglas. 1976. James Hogg. Edinburgh: The Ramsay Head Press.

Hogg, James. 1981. The Private Memoirs and Confessions of a Justified Sinner.Oxford: Oxford University Press.

Jacques-Allain Miller (ed). 1988. The Seminars of Jacques Lacan, translated by John Forrester.Cambridge: Cambridge University Press.

Sandeen, Ernest, 'The Scarlet Letter as a Love Story', in The Scarlet Letter, ed by Gross, Seymore, Bradley, Sculley, Beatty, Richmond Croom, Long, E. Hudson (W.W. Norton \& Company) pp. 350-361

Simpson, Louis, James Hogg, a Critical Study (Edinburgh and London: Oliver \&Boyd, 1962). 